\title{
Prescription for Obesity: Eat Less and Move More. Is It Really That Simple?
}

\author{
Karen M. Deck*, Beth Haney, Camille F. Fitzpatrick, Susanne J. Phillips, Susan M. Tiso \\ Core Faculty, Graduate Nursing Programs, University of California, Irvine, Irvine, CA, USA \\ Email: ${ }^{*}$ KDECK@uci.edu
}

Received 18 June 2014; revised 20 July 2014; accepted 8 August 2014

Copyright (C) 2014 by authors and Scientific Research Publishing Inc.

This work is licensed under the Creative Commons Attribution International License (CC BY). http://creativecommons.org/licenses/by/4.0/

(c) (i) Open Access

\begin{abstract}
"Obesity is a disease." This is the declaration by the American Medical Association in June, 2013. The purpose of this article is to provide an overview of options for patients who meet the criteria of obesity. Primary care nurse practitioners are urged to confront obesity head on, with early, individualized intervention to reduce associated morbidity and mortality. Options for weight loss and maintenance are abundant and often confusing or unattractive to the patient. Working with patients to achieve realistic, reasonable, and patient-tailored goals for weight loss and exercise programs are paramount to achieving a healthy weight and lifestyle.
\end{abstract}

\section{Keywords}

\section{Obesity Management Options}

\section{Introduction}

Elena, a 24-year-old Latina, presented to the community college student health center with low back pain for three months which has not improved with over-the-counter NSAIDS. Her body mass index (BMI) is $44 \mathrm{~kg} / \mathrm{m}^{2}$.

Natalia is a 45-year-old African American caregiver who presented to the local community clinic with worsening fatigue over the past year. She has a history of gestational diabetes with her last pregnancy, requiring insulin therapy. Her BMI is $38 \mathrm{~kg} / \mathrm{m}^{2}$.

Dan, a 64-year-old Caucasian attorney, is being evaluated for ultrasound-confirmed cholelithiasis. He has not had a physical examination over four years, although he has preferred provider organization (PPO) insurance with a private medical group. His BMI is $40 \mathrm{~kg} / \mathrm{m}^{2}$.

Do any of these vignettes sound familiar? They are typical of patients seen in primary care offices across many practice settings in the United States. Obesity is the common thread.

\footnotetext{
${ }^{*}$ Corresponding author.
}

How to cite this paper: Deck, K.M., Haney, B., Fitzpatrick, C.F., Phillips, S.J. and Tiso, S.M. (2014) Prescription for Obesity: Eat Less and Move More. Is It Really That Simple? Open Journal of Nursing, 4, 656-662. 
In June, 2013 the American Medical Association [1] classified obesity as a disease, creating discussion and controversy across healthcare settings. Regardless of how providers feel about this decision, it has forced us to confront the "elephant in the room." Obesity has commanded everyone's attention where it is widely discussed in the media and by political pundits. In an effort to address the issue, school lunches have been modified, vending machine options have changed and yet, America is becoming supersized. Obesity is an epidemic in the United States and prevalence has been increasing over the past several decades, affecting more than 35.7 percent of adults [2].

Obesity crosses all demographic indicators, including gender, age, ethnicity, and socioeconomic status [2]. Health risks associated with obesity include but are not limited to type 2 diabetes, heart disease, stroke, certain cancers, osteoarthritis, liver disease, obstructive sleep apnea, and depression [3]. The statistics for preventable death and all-cause mortality associated with obesity are compelling. According to the National Heart, Lung, and Blood Institute [4], the higher the body weight, the higher the rate for all-cause mortality. Mortality begins to increase with a BMI above $25 \mathrm{~kg} / \mathrm{m}^{2}$, especially from cardiovascular disease [4]. Obese individuals also have poorer quality of life, suffering from stigmatization, marginalization, and discrimination [4] [5].

In the broadest sense, providers will be encouraged to have conversations about weight, behavioral changes including dietary and activity modification, and interventions that may include pharmacotherapy, a referral to dieticians and other weight management professionals, support groups, established weight loss programs, and even bariatric surgery.

\section{Screening for Obesity}

One of the most accessible and widely performed clinical screening tools available is the BMI, which reflects the percentage of body fat and lean body mass [6]. The advantage to calculating BMI is the estimate of total body fat over body weight alone. However, BMI may overestimate obesity in individuals who are overweight due to increased muscle mass, i.e. bodybuilders and wrestlers. Conversely, BMI may also underestimate risk in certain Asian and Southeast Asian populations.

Current guidelines apply to Caucasian, Hispanic, and African-American individuals [6]. For the Asian population, overweight is diagnosed when the BMI is between $23-24.9 \mathrm{~kg} / \mathrm{m}^{2}$, and obesity is diagnosed when the $\mathrm{BMI}>25 \mathrm{~kg} / \mathrm{m}^{2}$ [7].

Obesity is defined as a BMI of greater than or equal to $30 \mathrm{~kg} / \mathrm{m}^{2}$ [8]. The classification of obesity can be further divided as follows (Table 1):

Table 1. Classification of obesity.

\begin{tabular}{ccc}
\hline Obesity Class 1 & Obesity Class 2 & Obesity Class 3 \\
\hline BMI of $30.0-34.9 \mathrm{~kg} / \mathrm{m}^{2}$ & BMI of $35.0-39.9 \mathrm{~kg} / \mathrm{m}^{2}$ & BMI $>40 \mathrm{~kg} / \mathrm{m}^{2}$ \\
\hline
\end{tabular}

Obesity Class 3 is also referred to as severe, extreme, or morbid obesity [6]. These classifications have been adopted by the National Institutes of Health, the World Health Organization, and are endorsed by most healthcare providers.

In addition to the BMI, waist circumference is an additional screening tool, measuring central adiposity or visceral fat. According to the NHLBI (1998), in adults with a BMI of $25-34.9 \mathrm{~kg} / \mathrm{m}^{2}$, a waist circumference of $>102 \mathrm{~cm}$ (40") for men and $88 \mathrm{~cm}$ (35”) for women indicates an increased risk for hypertension, diabetes, and hyperlipidemia. Waist circumference is measured with a flexible tape placed on a horizontal plane parallel to the floor at the level of the iliac crest, fitting snugly without compressing the skin at the end of normal exhalation. In patients with a BMI of $35 \mathrm{~kg} / \mathrm{m}^{2}$ or greater, waist measurement is unnecessary as a screening tool since the majority of these patients have central adiposity [4]. Additionally, there is a different criterion for obesity using waist measurement in Asian women [4].

\section{Pathophysiology: What Causes Obesity?}

Clearly, increased caloric intake and decreased activity results in an excess of calories that is stored as large 
adipose deposits. Certain medications, endocrine disorders, and lifestyle also contribute to obesity. Additionally, according to Bray, heredity may play a role in obesity citing studies of twins [8]. But is there another component as well?

Interestingly, the pathogenesis of obesity includes current research on genetic components related to satiety, food cues, and increased food intake in obese versus persons of normal weight. Several genetic models currently exist; Agouti gene, leptin, leptin receptor gene to name a few. A limited discussion on the role of genes will be included here.

Karra et al. [9], found a genetic predisposition involved in increased ad-lib food intake, "particularly fat consumption and impaired satiety." Additionally, frequent exposure to a high fat diet leads to an up-regulation in the fat mass and obesity-associated gene (FTO), which in turn leads to increased fat intake. According to Bray [8], "A variant in the FTO gene on chromosome 16 predisposes to type 2 diabetes through an effect on BMI." This variant is thought to contribute to approximately $22 \%$ of common obesity [10].

FTO regulates ghrelin, a hormone secreted in the gut that alters appetite and food intake. When ghrelin is increased, reduced satiety and increased food intake ensue [9]. Surprisingly, FTO also affects human responses to food images. In their 2013 study, Karra et al. found high calorie food images were rated significantly more appealing in post-prandial subjects with higher ghrelin levels [9]. Their findings indicate that altered ghrelin levels may contribute to increased appetite and food intake, especially fatty foods. It has been found that increased levels of ghrelin occur after diet-induced weight loss and this may explain the difficulty in maintaining the loss of weight [11]. Other hormones also play a role in weight gain. For example, in women, increased serum testosterone and decreased estrogen and growth hormone contributes to an increase in visceral fat and may help explain the weight gain associated with menopause [8].

\section{Current Weight Loss Options}

The ultimate goal of weight loss and maintenance of a healthy weight is to reduce health risks. Because many weight loss interventions are patient-driven, the key to success is initial assessment of the patient's motivation and willingness to participate in weight loss treatment. Secondly, individualizing care with attention to the patient's budget, time, interests, and access to the intervention are critical. Decreasing calories, increasing energy expenditure, and behavioral modification are the keys to successful weight loss. Weight loss goals should be defined in concert with the patient's input, but an initial realistic goal for weight loss is $10 \%$ of body weight over a six month time period at a rate of about one to two pounds per week. The bottom line for our patients is that they need to eat less and move more, but how do they achieve this?

\section{Eat Less: Diet}

Abundant clinical evidence suggests successful weight loss will be achieved by reducing food intake, rather than increasing exercise [4]. Decreasing calories by 500 - 1000 per day will achieve this; keeping in mind one pound of weight loss is equivalent to 3500 calories. Encourage patients to eat a well-balanced diet rich in lean protein sources such as poultry, lean meats, fish, beans, and peas. Dairy products such as fat-free or low-fat yogurt, milk, and cheeses should be included. Complex carbohydrates such as whole grain breads, cereals, brown rice and pasta are also good options. Fruit and vegetables-whether fresh, frozen, canned or dried are good choices as well. Preparing foods without added fats is also recommended [12]. A variety of spices and herbs may also be added to enhance flavor. Reducing both dietary fats and carbohydrates are necessary to produce the caloric deficit required. According to the National Cholesterol Education Program (NCEP) guidelines, total fat calories should not exceed $30 \%$ of the daily total [13].

\section{Move More: Exercise}

Lifestyle and behavioral modification including increased activity levels and exercise are critical to successful weight loss. Assessing patients' motivation, activities they enjoy, and their ability to exercise is a reasonable and important initial step that is often overlooked. Modification for patients with physical limitations such as arthritis must be considered, and working with a physical therapist may be a useful therapeutic option. Most patients may begin a walking program starting with 30 minutes a day five to seven times per week [14]. This time frame may be divided into increments for patients with time constraints. For example, most patients will be able to fit 
in a ten minute walk three times a day. Urging the patient to walk with a family member or friend may improve adherence to the program. Instructing the patient to walk fast enough to create perspiration but still be able to converse is a useful guideline. Simple interventions include recommending using stairs rather than the elevator, and parking at a distance and walking to their destination. Advise patients to wear absorbent socks, supportive shoes, and clothing appropriate for the climate with attention to sun protection for the skin. The exercise program prescription also will increase activity by 30 " per week as tolerated, and incrementally increased until a patient is exercising approximately 45” per day on 5 - 6 days per week. Evidence indicates exercise is a key element in maintaining weight loss [12].

\section{Pharmacotherapy}

Anti-obesity drugs are indicated along with lifestyle changes for select obese adults and BMI greater than 30 $\mathrm{kg} / \mathrm{m}^{2}$, who have failed to achieve weight loss goals through diet and exercise alone [4]. A trial of drug therapy is also warranted in patients with a BMI $27-29.9 \mathrm{~kg} / \mathrm{m}^{2}$ with co-morbidities, or in patients for whom gastrointestinal bypass surgery is being considered [4].

Medications work by allowing patients to feel less hungry or feel full sooner. It is not within the scope of this article to explore all of the pharmacological agents used to treat obesity. The most commonly used agents are included in Table 2.

A comprehensive weight control approach for co-morbid conditions associated with obesity is advised. According to the Diabetes Research Program Prevention Group, treatment of Type II diabetes with Metformin does not cause weight gain, and in some patients may result in weight loss [15]. Exenatide, Liraglutide, and Pramlintide have been shown to cause weight loss. In patients with depression and obesity, the nurse practitioner should be cognizant of medications that promote weight gain and prescribe those drugs that are at least weight-neutral. Bupropion, an antidepressant, has been shown to cause weight loss when used for smoking cessation [16].

In the lay community, hormone therapy such as human chorionic gonadotropin (HCG) is commonly requested in conjunction with a very low calorie diet ( $500 \mathrm{kcal} / \mathrm{day}$ ). Trials have demonstrated the HCG diet is not more effective than placebo in the treatment of obesity [17]. Therefore, there is insufficient evidence for use of HCG in the treatment of obesity.

Finally, diet supplements are frequently used by patients, however, a full exploration of these is beyond the scope of this paper. Currently, there are no evidence based guidelines supporting the use of dietary supplements for the treatment of obesity. In fact, the use of ephedra for weight loss has been demonstrated to be unsafe [18]. Obese patients treated with medication should be advised that medications in combination with lifestyle changes will have the greatest impact on sustained weight loss.

\section{Surgery}

Bariatric surgery is an option for carefully selected patients with extreme obesity, (BMI $>40 \mathrm{~kg} / \mathrm{m}^{2}$ ), those with comorbidities and a BMI $\geq$ to $35 \mathrm{~kg} / \mathrm{m}^{2}$, and for those in whom other interventions have failed [19]. Since it is not within the scope of this article, the most commonly performed procedures, risks and benefits, and considerations will be discussed in a future paper.

\section{Behavioral Modification}

The goal of any weight loss program is to return to a healthy weight and BMI. The key to all weight loss programs or behavior modification strategies is to maintain the weight loss and a healthy weight for the long-term by setting quick, sustainable, realistic goals. Many people find the diet plans promoted in the media attractive and may possibly obtain a temporary weight loss only to experience recurrent weight gain in a vicious cycle of brief success followed by failure [20].

The cornerstone of a successful weight loss program includes a combination of exercise, healthy diet, and behavioral modification. Behavioral modification will be discussed here and it is a crucial intervention, helping to control external and emotional cues that may trigger eating.

According to Bray, there are two basic assumptions that underlie behavioral therapy for overweight patients: 1) Obese individuals have learned and sustained maladaptive eating patterns and exercise habits; 2) These behaviors can be altered through education and practice and weight loss will occur. "Thus, behavioral treatment for 
the overweight patient seeks to alter the environment, to alter environmental reinforcement contingencies, and to shape eating behavior and physical activity" [21].

There are many reasons which explain the high failure rate of dieters who attempt to lose weight including but not limited to having unrealistic expectations, expectations they will change more quickly than possible, and overestimating their ability to sustain change or incorporate new habits [20]. Another element that contributes to diet failure is the patient's belief they are not trying hard enough which results in self-recrimination. The clinician may then try to change the diet program or find something new for the patient. These scenarios result in patient frustration and high failure rates [20].

Components of behavior modification strategies incorporate food diaries, exercise logs, meal planning, social and group support, nutrition education, and cognitive restructuring. However, the most crucial factor has been lifestyle modification consisting of diet, exercise, and behavior modification [20]. For lifestyle modification techniques to be sustained for long lasting weight management, the Diabetes Prevention Program (DPP) reported frequent feedback and communication is necessary through individual counselors, group sessions, and clinical support. They also reported better diabetic control with behavior modification than with pharmacologic intervention [15].

Behavior modification through group or individual programs has been successful in helping patients achieve their goals. One program that patients may find beneficial is the Lifestyle, Exercise, Attitudes, Relationships, Nutrition (LEARN) Program created by Kelly Brownell, Ph.D. self-monitoring through food diary and exercise log use has led to long-term weight management in patients [13].

Another intervention for weight loss includes gaining control over the environment. For example, avoiding high fat, calorie rich food and purchasing fresh fruit and vegetables and displaying them prominently in the refrigerator or on the counter encourage healthier eating. When eating, patients should chew slowly, turn off the television, stop other activities, and concentrate on the meal to avoid mindless eating and over-consumption [13].

Furthermore, setting realistic goals is essential for success. Realistic goal-setting must be developed in partnership with the patient to provide a sense of ownership and responsibility on the patient's part and also to engage the patient in their treatment plan. If the patient has no input into the plan, they may feel as if the goals are unrealistic or un-motivating.

Certain reinforcements may be beneficial for patient success such as financial incentives, gifts, or other tokens of achievement. In addition, social support consisting of family members or a friend can assist the patient with weight loss success [20]. Meal plans with specific outlines also appear beneficial as well as increasing physical activity equal to approximately one hour a day of moderate intensity exercise such as brisk walking [20].

Although millions of people enroll in them each year, a systematic review by Tsai \& Wadden on commercial weight loss programs have demonstrated little efficacy [22]. The weight loss programs reviewed were eDiet at https://www.ediets.com/, Health Management Resources, Take Off Pounds Sensibly, OPTIFAST, and Weight Watchers. Of these programs, Weight Watchers had three randomized controlled trials and demonstrated the largest loss at only $3.2 \%$ of initial weight at two years.

A subsequent trial looked at Jenny Craig and found similarly disappointing results [23]. Internet-based weight loss program results are mixed. However, it appears the programs that incorporate behavior modification have better results [12].

Behavioral modification also appears to be effective in children and adolescents but to be successful, it should include parental involvement and increasing physical activity [24] [25].

Lastly, other methods can be useful in weight management and behavior modification include learning to say "no,” preparing food ahead of time, managing stressful eating situations like parties, positive thinking training, and identifying triggers and stressors that lead to eating.

\section{Implications for Practice}

Not unlike "an elephant in the room," the obesity epidemic continues to expand in the United States. Nurse practitioners are urged to be current regarding the most recent guidelines for obesity screening, methods of evidence-based intervention, and identification of community resources within a radius of one's clinical practice. Also, assess the patient's readiness and motivation for change through effective communication skills and sensitivity for culture, budget, and social support. Establish a partnership based upon early, realistic goal-setting and 
comprehensive continuity of care. Along the journey, more aggressive interventions such as pharmacotherapy and bariatric surgery can be considered. As with all disease management, the goal of treating obesity is amelioration of obesity-related health risks and improved quality of life.

\section{Statements}

The content of this article is original, has not been published elsewhere, and is submitted for exclusive consideration by the Open Journal of Nursing.

Table 2. Pharmacotherapy for treatment of obesity [26] [27].

\begin{tabular}{|c|c|c|c|c|}
\hline $\begin{array}{c}\text { Name of } \\
\text { drug/dosage }\end{array}$ & $\begin{array}{c}\text { Drug Class/ } \\
\text { Mechanism of action }\end{array}$ & Adverse effects & $\begin{array}{c}\text { Precautions/ } \\
\text { Contraindications }\end{array}$ & Notes \\
\hline $\begin{array}{l}\text { Orlistat } \\
\text { (Xenical } 120 \mathrm{mg} \\
\text { TID, Alli } 60 \mathrm{mg} \\
\text { TID, OTC) }\end{array}$ & $\begin{array}{l}\text { Gastrointestinal lipase } \\
\text { inhibitor, alters fat } \\
\text { absorption and fecal } \\
\text { fat excretion increased }\end{array}$ & $\begin{array}{l}\text { Oily, fecal incontinence, } \\
\text { GI complaints }\end{array}$ & $\begin{array}{l}\text { May alter fat soluble vitamin } \\
\text { absorption; diet intake of fat }<30 \%\end{array}$ & $\begin{array}{l}\text { May be used safely } \\
\text { long-term. Does not } \\
\text { interfere with any } \\
\text { other medication. }\end{array}$ \\
\hline $\begin{array}{l}\text { Lorcaserin } \\
\text { (Belviq) } \\
10 \text { mg QID }\end{array}$ & $\begin{array}{l}\text { Centrally acting } \\
\text { 2C/serotonin agonist }\end{array}$ & $\begin{array}{l}\text { Mild, headache, nausea: } \\
\text { hypoglycemia in diabetics }\end{array}$ & $\begin{array}{l}\text { Efficacy similar to Orlistat. } \\
\text { Contraindicated with other } \\
\text { SSRIs. Caution in patients } \\
\text { with valvular heart disease, } \\
\text { cognitive impairment, psychiatric } \\
\text { disorders, pulmonary HTN. }\end{array}$ & \\
\hline $\begin{array}{l}\text { Phentirmine } \\
\text { (Adipex) } \\
\text { Diethylpropion } \\
\text { (Tenuate) }\end{array}$ & $\begin{array}{l}\text { Sympathomimetic, } \\
\text { appetite suppressant. } \\
\text { Induce early satiety. }\end{array}$ & $\begin{array}{l}\text { CNS stimulation: } \\
\text { Hypertension, tachycardia, } \\
\text { irritability, palpitations, } \\
\text { insomnia, nervousness etc. }\end{array}$ & $\begin{array}{l}\text { Approved for only up to } 12 \\
\text { weeks of therapy. Contraindicated } \\
\text { in patients with hypertension, } \\
\text { hyperthyroidism, and glaucoma. }\end{array}$ & $\begin{array}{l}\text { Schedule IV drugs } \\
\text { with low potential } \\
\text { for abuse. }\end{array}$ \\
\hline $\begin{array}{l}\text { Phentirmine/ } \\
\text { Topiramate } \\
\text { (Qsymia) }\end{array}$ & $\begin{array}{l}\text { Centrally acting } \\
\text { 2C/serotonin agonist } \\
\text { appetite suppressant and } \\
\text { anti-seizure medicine }\end{array}$ & $\begin{array}{l}\text { Same as above, with additional } \\
\text { paresthesia, dizziness, dysgeusia, } \\
\text { insomnia, constipation, dry mouth. }\end{array}$ & $\begin{array}{l}\text { Consider in post-menopausal } \\
\text { women and men without } \\
\text { cardiovascular disease; increased } \\
\text { risk of suicide and seizures with } \\
\text { abrupt withdrawal. }\end{array}$ & \\
\hline
\end{tabular}

\section{References}

[1] American Medical Association (2013) Recognition of Obesity as a Disease. Resolution 420, (A-13). http://media.npr.org/documents/2013/jun/ama-resolution-obesity.pdf

[2] Centers for Disease Control (2012) Overweight and Obesity. http://www.cdc.gov/obesity/data/adult.html

[3] Adams, K.F., Schatzkin, A., Harris, T.B., Kipnis, V., Mouw, T., Ballard-Barbash, R. and Leitzmann, L.F. (2006) Overweight, Obesity, and Mortality in a Large Prospective Cohort of Persons 50 to 71 Years Old. New England Journal of Medicine, 355, 763-778. http://dx.doi.org/10.1056/NEJMoa055643

[4] National Heart, Lung, and Blood Institute (1998) Clinical Guidelines on the Identification, Evaluation, and Treatment of Overweight and Obesity in Adults. http://www.cdc.gov/obesity/data/adult.html

[5] Newman, C. (2003) Why Are We So Fat? National Geographic. http://science.nationalgeographic.com/science/health-and-human-body/human-body/fat

[6] Bray, G.A. (2013) Screening for and Clinical Evaluation of Obesity in Adults. http://www.uptodate.com/contents/screening-for-and-clinical-evaluation-of obesity-in-adults costs.html

[7] Bray, G.A., Wang, Y.C., McPherson, K., Gortmaker, S.L., Brown, M. (2011) Heath and Economic Burden of the Projected Obesity Trends in the USA and the UK. Lancet, 378, 815-825. http://dx.doi.org/10.1016/S0140-6736(11)60814-3

[8] Bray, G.A. (2013) Pathogenesis of Obesity.http://www.uptodate.com/contents/pathogenesis-of-obesity?topic

[9] Karra, E., O’Daly, O.G., Choudhury, A.I., Yousseif, A., Millership, S., Neary, M.T. and Batterham, R.L. (2013) A Link between FTO, Ghrelin, and Impaired Brain Food-Cue Responsivity. Journal of Clinical Investigation. http://dx.doi.org/10.1172/JCI44403

[10] Dina, C., Mayre, D., Gallina, S., Durand, E., Korner, A., Jacobson, P. and Chevre, J.C. (2007) FTO Contributes to Childhood Obesity and Severe Adult Obesity. National Genetics, 39, 724-726. http://dx.doi.org/10.1038/ng2048

[11] Cummings, D.E., Weigle, D.S., Frayo, R.S., Breen, P.A., Ma, M.K., Dellinger, E.P. and Purnell, J.Q. (2002) Plasma 
Ghrelin Levels after Diet-Induced Weight Loss or Gastric Bypass Surgery. New England Journal of Medicine, 346, 1623-1630. http://dx.doi.org/10.1056/NEJMoa012908

[12] Bray, G.A. (2013) Behavioral Strategies in the Treatment of Obesity. http://www.uptodate.com/contents/behavioral-strategies-in-the-treatment-obesity

[13] National Cholesterol Education Program (2004) Third Report of the Expert Panel on Detection, Evaluation, and Treatment of High Blood Cholesterol in Adults (Adult Treatment Panel III). http://www.nhlbi.nih.gov/guidelines/cholesterol/

[14] Bray, G.A. (2014) Obesity in Adults: Role of Physical Activity and Exercise. http://www.uptodate.com/contents/obesity-in-adults-role-of-physical-activity-and-exercise?source=see_link

[15] Diabetes Prevention Program Research Group (2012) Description of Lifestyle Intervention. Diabetes Care, $25,2165$.

[16] Anderson, J.W., Greenway, F.L., Fujioka, K., Gadde, K.M., McKenney, J. and O’Neil, P.M. (2002) Bupropion SR Enhances Weight Loss: A 48-Week Double-Blind, Placebo-Controlled Trial. Obesity Resource, 10, 633-641. http://dx.doi.org/10.1038/oby.2002.86

[17] Bosch, B., Venter, I., Stewart, R.I. and Bertram, S.R. (1990) Human Chorionic Gonadotrophin and Weight Loss. A Double-Blind, Placebo-Controlled Trial. South African Medical Journal, 77, 185-189.

[18] Saper, R.B., Eisenberg, D. and Phillips, R.S. (2004) Common Dietary Supplements for Weight Loss. American Family Physician, 70, 1731-1738. http://www.aafp.org/afp/2004/1101/p1731.html

[19] Andrews, R.A. and Lim, R.B. (2013) Surgical Management of Severe Obesity. http://www.uptodate.com/contents/surgical-management-of-severe-obesity?topicKey+SU

[20] Bray, G.A., Wing, R.R. and Phelan, S. (2005) Long-Term Weight Loss Maintenance. American Journal of Clinical Nutrition, 82, 222S-225S.

[21] Wing, R.R. and Phelan, S. (2005) Long-Term Weight Loss Maintenance. American Journal of Clinical Nutrition, 82, 222S-225S.

[22] Tsai, A.G. and Wadden, T.A. (2005) Systematic Review: An Evaluation of Major Commercial Weight Loss Programs in the United States. Annals of Internal Medicine, 142, 56-66. http://dx.doi.org/10.7326/0003-4819-142-1-200501040-00012

[23] Rock, C.L., Flatt, S.W., Sherwood, N.E., Karanja, N., Pakiz, B. and Thomson, C.A. (2010) Effect of a Free Prepared Meal and Incentivized Weight Loss Program on Weight Loss and Weight Loss Maintenance in Obese and Overweight Women: A Randomized Controlled Trial. Journal of the American Medical Association, 304, 1803-1810. http://dx.doi.org/10.1001/jama.2010.1503

[24] Epstein, L.H., Valoski, A.M., Vara, L.S., McCurley, J., Wisniewski, L., Kalarchian, M.A. and Schrager, L.R. (1995) Effects of Decreasing Sedentary Behavior and Increasing Activity on Weight Change in Obese Children. Health Psychology, 14, 109-115. http://dx.doi.org/10.1037/0278-6133.14.2.109

[25] Epstein, L.H., Valoski, A., Wing, R.R. and McCurley, J. (1990) Ten-Year Follow-Up of Behavioral, Family-Based Treatment for Obese Children. Journal of the American Medical Association, 264, 2519-2523. http://dx.doi.org/10.1001/jama.1990.03450190051027

[26] Correction-Pharmacist’s Letter (2012) Drugs for Weight Loss. 28, 281109. http://pharmacistsletter.therapeuticresearch.com/(S(dtw2xcbii4blw545izo32z45))/pl/ArticleDD.aspx?nidchk=1\&cs=ce \&s=PL\&pt $=2 \& d d=280811$

[27] Wong, E., Kaur, N., Patel, K. and Ringal, M. (2013) Obesity: A Focus on Pharmacotherapy. The Journal for Nurse Practitioners, 9, 388-395. http://dx.doi.org/10.1016/j.nurpra.2013.03.015 
Scientific Research Publishing (SCIRP) is one of the largest Open Access journal publishers. It is currently publishing more than 200 open access, online, peer-reviewed journals covering a wide range of academic disciplines. SCIRP serves the worldwide academic communities and contributes to the progress and application of science with its publication.

Other selected journals from SCIRP are listed as below. Submit your manuscript to us via either submit@scirp.org or Online Submission Portal.
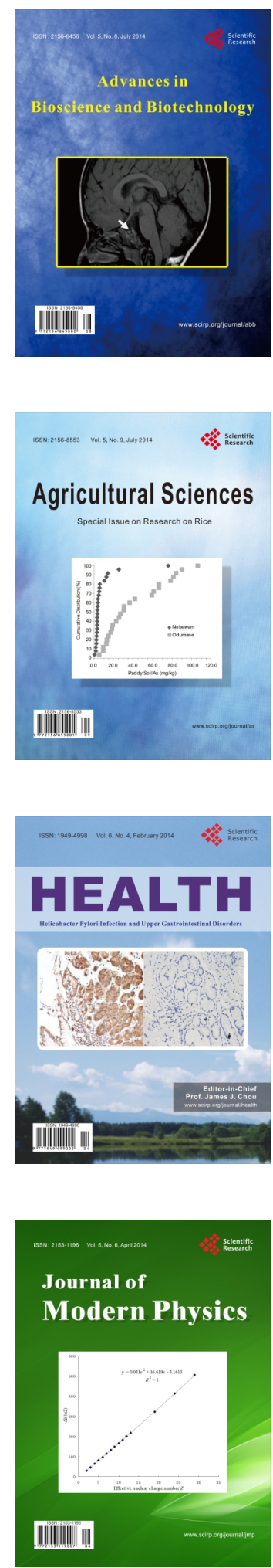
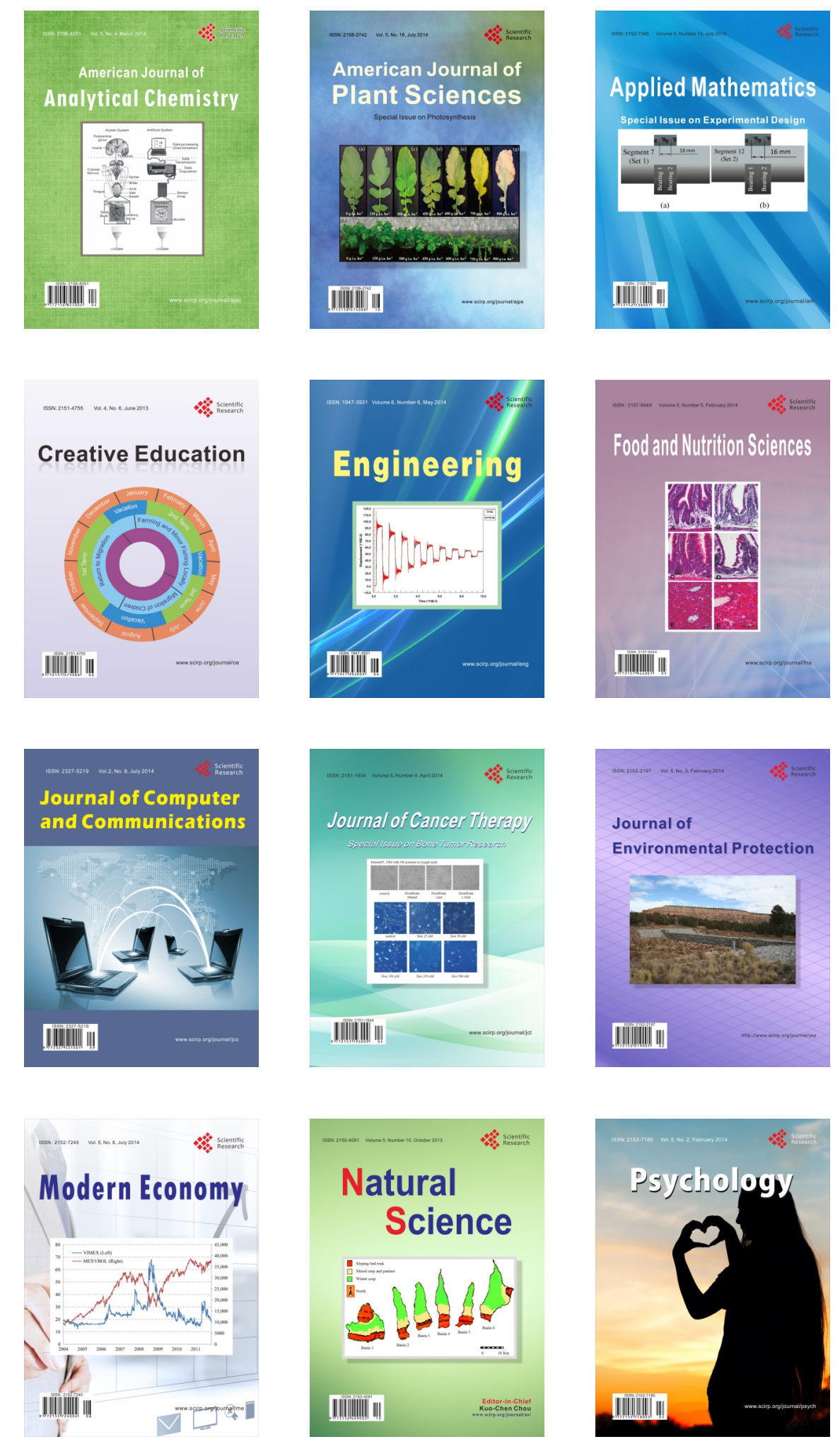